\title{
Antioxidant Enzyme Activity and Gene Expression in Response to Lead Stress in Perennial Ryegrass
}

\author{
Huiying Li and Hongji Luo \\ Key Laboratory of Plant Germplasm Enhancement and Specialty Agriculture, Wuhan Botanical \\ Garden, The Chinese Academy of Science, Lumo Street, Wuhan City, Hubei 430074, People's \\ Republic of China \\ Deying Li \\ Department of Plant Sciences, North Dakota State University, Fargo, ND 58108 \\ Tao Hu and Jinmin $\mathbf{F u}^{1}$ \\ Key Laboratory of Plant Germplasm Enhancement and Specialty Agriculture, Wuhan Botanical \\ Garden, The Chinese Academy of Science, Lumo Street, Wuhan City, Hubei 430074, People's \\ Republic of China
}

\begin{abstract}
AdDitional INDEX wORDs. heavy metal, pollution, physiology, tolerant, Lolium perenne
Abstract. Lead pollution is an important issue in the world. Perennial ryegrass (Lolium perenne), as one of the widely used turfgrass and forage species, has a potential for bioremediation. The objective of this study was to investigate how antioxidant enzymes and their gene transcripts respond to $\mathrm{Pb}$ stress in perennial ryegrass. Ryegrass seedlings were subjected to $0,0.5$, and $3.2 \mathrm{~mm}$ of $\mathrm{Pb}\left(\mathrm{NO}_{3}\right)_{2}$ for 7 days in a hydroponic system maintained in a greenhouse. Both root and shoot growths were inhibited by $\mathrm{Pb}$ compared with the control. However, contents of chlorophyll (Chl) $a$ and total $\mathrm{Chl}$ were unaffected by $\mathrm{Pb}$ treatment. Results from this study showed a substantial increase of malondialdehyde (MDA) content in leaf tissues when perennial ryegrass was exposed to $\mathrm{Pb}$ at $3.2 \mathrm{~mm}$. The MDA content from plants in the $0.5 \mathrm{~mm} \mathrm{~Pb}$ treatment was lower than the control, indicating that an effective defense mechanism existed. Circumstantial evidence came also from the content of soluble protein in $0.5 \mathrm{~mm} P b$ treatment, which was not different from the control. Furthermore, the activity of catalase (CAT) increased at $0.5 \mathrm{~mm} \mathrm{~Pb}$ compared with the control, indicating that CAT might play an important role in scavenging reactive oxygen species (ROS). The expression profiles of eight genes encoding antioxidative enzymes were upregulated within 24 hours of $\mathrm{Pb}$ treatment. In conclusion, antioxidant enzymes responded to $\mathrm{Pb}$ at an early stage of exposure and their gene expression profiles provided more details in time courses of the activation of those systems.
\end{abstract}

Heavy metal pollution is a worldwide ecological problem because of its impact on plants and animals and ultimately on the health of human beings via the food chain. Lead is one of the most abundant and widely distributed heavy metals because of its various human activities, such as mining and smelting of lead ores, paint manufacturing, gasoline production, lead linings, and so on. As a result, $\mathrm{Pb}$ is readily enriched into ecosystems. As a nonessential element for plants, $\mathrm{Pb}$ impedes plant growth by affecting physiological process and metabolic pathways such as photosynthesis and nutrient acquisition (Godbold and Kettner, 1991; Kastori et al., 1992; Rashid and Popovic, 1990; Verma and Dubey, 2003).

Like many other toxic metals, $\mathrm{Pb}$ induces production and accumulation of free radicals and ROS in plant tissues and causes oxidative stress in plants. Excessive ROS can result in irreversible oxidization of lipids, proteins, chloroplastic pigments, and nucleic acids (Foyer et al., 1994; Malecka et al., 2001; Reddy et al., 2005; Schutzendubel and Polle, 2002; Verma and Dubey, 2003). Plants have developed both enzymatic and nonenzymatic defense systems to scavenge and detoxify ROS (Mittler, 2002).

Received for publication 27 Oct. 2011. Accepted for publication 30 Dec. 2011 This research was supported by Rural Areas of National Science Research for the 12th Five-Year Plan (Project No. 2011AA100209-2), Innovative Program of The Chinese Academy of Sciences (Project No. KSCX2-YW-N-068), and AcademyLocality Cooperation Programme (Project No. 2B201131161101616).

${ }^{1}$ Corresponding author. E-mail: jinminfu@gmail.com
For example, enhanced activities of superoxide dismutase (SOD), peroxidase (POD), glutathione reductase (GR), and other antioxidative enzymes were detected in both horse gram (Macrotyloma uniflorum) and bengal gram (Cicer arietinum) subjected to $\mathrm{Pb}$, and the levels of enzymes were dependent on the concentration of $\mathrm{Pb}$ (Reddy et al., 2005). Increased levels of POD and $\mathrm{GR}$, in response to $\mathrm{Pb}$, were also reported in Arabidopsis thaliana and maize (Zea mays) calli (Verma and Dubey, 2003; Zacchini et al., 2003). Elevated levels of antioxidant enzymes including SOD, glutathione peroxidase (GPX), ascorbate peroxidase (APX), GR, and CAT were found in coontail (Ceratophyllum demersum) when exposed to $\mathrm{Pb}$ (Mishra et al., 2006). On the contrary, there were also reports indicating decreased or unchanged activities of SOD and POD in plants subjected to $\mathrm{Pb}$ or other heavy metals (Islam et al., 2008; Liu et al., 2008; Sun et al., 2009). The discrepancies regarding the responses of SOD and POD to Pb stress may attribute to the different metal concentrations and/or plant developmental stages at which the investigations were conducted.

Plant responses to $\mathrm{Pb}$ have been studied at gene levels using DNA microarray technique, which overcame some of the disadvantages related to enzyme analysis (Magrini et al., 2008). Upregulated expressions were observed for type-2 metallothionein, aminocyclopropane carboxylic acid synthase/oxidase, and other genes induced by abiotic stress in rattlebox (Sesbania drummondii) subjected to $\mathrm{Pb}$ treatment (Srivastava et al., 2007). Using quantitative real-time polymerase chain reaction (Q-PCR) 
technique, Brunet et al. (2009) detected the increased expression of GR, APX, and glutathione S-transferase gene in the roots of grass pea (Lathyrus sativus) exposed to $\mathrm{Pb}$ for $96 \mathrm{~h}$ in a hydroponic system. Kovalchuk et al. (2005) analyzed the global genome expression of transgenic $A$. thaliana plants chronically exposed to $\mathrm{Pb}$ using $\mathrm{DNA}$ microarray technique and revealed 19 upregulated genes and 76 downregulated genes. Liu et al. (2009) reported that more than 1310 genes were affected in the expression profiles of $A$. thaliana in response to different concentrations of $\mathrm{Pb}(1,10$, and $100 \mu \mathrm{M})$ during the early stage of treatment, and most of the upregulated genes were also found under other stress. The genetic techniques provided effective tools to investigate plant responses to heavy metals and can be supplementary to those used at enzyme levels.

Perennial ryegrass is one of the most widely used species for turf and forage in temperate regions (Bidar et al., 2007; Wilkins and Humphreys, 2003). Perennial ryegrass is capable of accumulating heavy metals (Pichtel and Salt, 1998) and was defined as a facultative metallophyte by Smith and Bradshaw (1979). Arienzo et al. (2004) reported that a healthy vegetation of ryegrass could be established on metal-polluted soils. Carlson and Rolfe (1979) found that the growth of perennial ryegrass did not begin to decrease until $\mathrm{Pb}$ treatment reached $1000 \mu \mathrm{g} \cdot \mathrm{g}^{-1}$. Little is known about the mechanisms driving the responses in perennial ryegrass to $\mathrm{Pb}$. Understanding of the physiological responses and transcription profiles of the genes coding for antioxidant enzymes in perennial ryegrass under $\mathrm{Pb}$ stress can provide valuable information and assessment tools to breeders.

The objectives of this study were to investigate the physiological responses of perennial ryegrass seedlings to a wide range of $\mathrm{Pb}$ concentrations concerning both antioxidant enzymes and transcription profiles of the genes coding for those enzymes.

\section{Material and Methods}

Plant materials. Perennial ryegrass 'Quickstart II' was seeded to plastic pots $(7.5 \mathrm{~cm}$ diameter and $9.0 \mathrm{~cm}$ deep) with sand medium in July 2010. The pots were watered twice daily and fertilized twice weekly with half-strength Hoagland's solution (Hoagland and Arnon, 1950) until germination. Thereafter, the plants were watered daily to pot capacity and clipped at $8 \mathrm{~cm}$ above the soil surface. The plants were maintained in a greenhouse with a 14-h light period from natural light and temperatures of $20 / 16{ }^{\circ} \mathrm{C}$ (day/night).

Treatments. At about seven-leaf stage, $40 \mathrm{~d}$ after germination, the plants were transplanted into 300-mL conical flasks containing $290 \mathrm{~mL}$ half-strength Hoagland's solutions, after the roots were washed free of sand using distilled water. The Hoagland nutrition contained also $0.1 \mu \mathrm{M}$ of $\mathrm{CaO}_{2}$ for providing plants additional oxygen. The flasks were wrapped with aluminum foil to block light. Ten plants were maintained in each flask. After 1 week of adaptation in the hydroponics system, the plants were transferred to new flasks and subjected to $\mathrm{Pb}$ treatments by adding $0,0.5$, and $3.2 \mathrm{mmol} \cdot \mathrm{L}^{-1} \mathrm{~Pb}\left(\mathrm{NO}_{3}\right)_{2}$ to the half-strength Hoagland's solution containing $\mathrm{CaO}_{2}$. During the period of experiment, the nutrient solution was supplemented every $2 \mathrm{~d}$. The experiment was arranged in a randomized complete block design with five replicates and each flask as one treatment unit. Two identical experiments were established for the measurements of enzymes and gene expression analysis, respectively.
Growth AND ENZYME. Shoot and root length were measured at $7 \mathrm{~d}$ after $\mathrm{Pb}$ treatment. Immediately following the measurement of plant growth, leaves were harvested, weighed, and frozen in liquid nitrogen before storing under $-70^{\circ} \mathrm{C}$ for further measurement of Chl content, SOD, CAT, POD, MDA, and soluble protein using the following procedures.

Chlorophyll content in leaves was measured by the method of Hiscox and Israelstam (1979). In summary, $0.1 \mathrm{~g}$ of fresh leaves was cut into small pieces and placed into $15-\mathrm{mL}$ tubes containing $10 \mathrm{~mL}$ of dimethylsulfoxide (DMSO). The tubes were kept under $25{ }^{\circ} \mathrm{C}$ in darkness for $48 \mathrm{~h}$ and shaken $15 \mathrm{~s}$ every $12 \mathrm{~h}$ for thorough mixing of the extraction. Thereafter, $1 \mathrm{~mL}$ extraction was transferred into a new tube and $2 \mathrm{~mL}$ of DMSO was added for dilution. The diluted samples were mixed and immediately measured for light absorption at 645 and $663 \mathrm{~nm}$. The content of Chl $a$ and Chl $b$ (milligram per gram fresh weight) was calculated based on the equations developed by Hiscox and Israelstam (1979).

For enzyme extraction, $\approx 0.3 \mathrm{~g}$ of leaf samples were homogenized with $5 \mathrm{~mL}$ of $50 \mathrm{~mm}$ buffer solution (containing $0.7 \%$ of $\mathrm{NaH}_{2} \mathrm{PO}_{4} \cdot 2 \mathrm{H}_{2} \mathrm{O}$ and $1.64 \% \mathrm{Na}_{2} \mathrm{HPO}_{4} \cdot 12 \mathrm{H}_{2} \mathrm{O}, \mathrm{pH} 7.8$ ) subjected to grinding with an ice-cooled mortar and pestle and finally centrifuged at $5000 g_{n}$ for $25 \mathrm{~min}$ at $4{ }^{\circ} \mathrm{C}$. The supernatant was collected for the determination of soluble protein content, SOD, CAT, and POD activity, and MDA content. CAT and POD activities were determined following the method described by Chance and Maehly (1955). SOD activity was measured according to the method used by Chowdhury and Choudhuri (1985) and Zhang and Kirkham (1994). The content of MDA was determined according to the method of Heath and Packer (1968). The total soluble protein content was estimated using bovine serum albumin as a standard (Bradford, 1976).

GENE EXPRESSION OF ANTIOXIDANT ENZYMES. Leaf samples were collected at 2, 4, 6, 24, and $48 \mathrm{~h}$ after the initiation of $\mathrm{Pb}$ treatment and flash frozen in liquid nitrogen and then stored at $-70{ }^{\circ} \mathrm{C}$ for gene expression analysis.

Total RNA was isolated from $\approx 0.1 \mathrm{~g}$ leaves of each treatment using Trizol reagent (Invitrogen, Carlsbad, CA) and then treated with RNase-free DNase I to remove DNA. The quality of RNA was examined by electrophoresis in $1.5 \%$ agarose gel. Concentration of RNA was determined using a spectrophotometer and then diluted to $400 \mathrm{ng} \cdot \mu \mathrm{L}^{-1}$ using RNase free water; $2 \mu \mathrm{g}$ RNA was reversely transcribed with oligo (dT) primer using first strand cDNA synthesis kit (Fermentas Canada, Burlington, ON, Canada) following the manufacturer's instructions. The resultant cDNA was then diluted 10 times and kept at $-20{ }^{\circ} \mathrm{C}$ for Q-PCR.

Primers of different genes were synthesized based on the previous reports for use in Q-PCR (Table 1). The specification of each pair of primers was confirmed by randomly sequencing PCR products and further consolidated by the melting curve analysis using Q-PCR. The amplification efficiency of each pair of primers was tested by constructing corresponding plasmid. Only primers with amplification efficiency above 95\% were used in this study. The Q-PCR was conducted with SYBR Green I (Sigma-Aldrich, St. Louis, MO) as a fluorogenic intercalating dye on a Chromo4 Real-Time Detection System (MJ Research, Cambridge, MA). Each $20 \mu \mathrm{L}$ of reaction solution contained $3.5 \mathrm{mmol} \cdot \mathrm{L}^{-1} \mathrm{MgCl}_{2}, 1$ unit PCR buffer, $0.5 \mu \mathrm{M} \cdot \mathrm{L}^{-1}$ of each primer, $10 \mu \mathrm{M} \cdot \mathrm{L}^{-1} \mathrm{dNTPs}, 0.5$ unit SYBR Green I, 1 unit Taq polymerase (Fermentas Canada), 0.6 $\mu \mathrm{L}$ DMSO (Sigma-Aldrich), and $1.5 \mu \mathrm{L}$ of template cDNA. A parallel 
control containing no templates was run to determine contaminations and formation of primer dimers. An internal control using $e E F 1 A$ (s) gene also was included. The conditions and parameters for PCR were as follows: an initial denaturing step at $95{ }^{\circ} \mathrm{C}$ for $3 \mathrm{~min}$, followed by 40 cycles of $94{ }^{\circ} \mathrm{C}$ for $15 \mathrm{~s}, 50-55^{\circ} \mathrm{C}$ for $20 \mathrm{~s}$, and $72{ }^{\circ} \mathrm{C}$ for $20 \mathrm{~s}$. Melting curve analysis of the amplification products was performed at the end of each PCR reaction to ensure that a single PCR product was detected. The PCR amplification data were analyzed with Option Monitor version 2.03 (MJ Research).

Statistics. One-way analysis of variance was conducted using SPSS (version 17.0; IBM Corp., Armonk, NY). Treatment means were separated using Fisher's least significant difference at 0.05 significant levels.

\section{Results}

Plant growth and stress. Shoot and root length of perennial ryegrass decreased with increasing $\mathrm{Pb}$ concentrations (Table 2). The concentration of Chl $a$ and total Chl was not affected by $\mathrm{Pb}$ treatment (Table 2). At $3.2 \mathrm{~mm}$ of $\mathrm{Pb}$, perennial ryegrass showed a higher level of Chl $b$ compared with the control and $0.5 \mathrm{~mm} \mathrm{~Pb}$ treatment. MDA content increased substantially in the $3.2 \mathrm{~mm}$ $\mathrm{Pb}$ treatment compared with the control. On the contrary, MDA content in the $0.5 \mathrm{~mm} \mathrm{~Pb}$ treatment was lower than the control (Table 3). Soluble protein content decreased when the concentration of $\mathrm{Pb}$ increased to $3.2 \mathrm{~mm}$ (Table 3 ).

ACTIVITY OF ANTIOXIDANT ENZYMEs. The plants treated with $0.5 \mathrm{~mm} \mathrm{~Pb}$ exhibited elevated CAT activity compared with the control, whereas plants treated with $3.2 \mathrm{~mm}$ of $\mathrm{Pb}$ showed suppressed CAT activity compared with the control (Table 4). The levels of POD in $0.5 \mathrm{~mm} \mathrm{~Pb}$-treated plant did not change compared with the untreated plants. However, there was a higher activity of POD in $3.2 \mathrm{~mm} \mathrm{~Pb}$ treatment than both untreated and $0.5 \mathrm{~mm}$ treatment (Table 4 ). The SOD activity was inhibited in $\mathrm{Pb}$-treated plants compared with the control. Higher concentration of $\mathrm{Pb}$ resulted in more inhibition. The SOD activity of plants exposed to 3.2 and $0.5 \mathrm{~mm} \mathrm{~Pb}$ was $74 \%$ and $55 \%$ lower than the control, respectively (Table 4).

GENE EXPRESSION OF ANTIOXIDANT ENZYMES. The expressions of $M n S O D$ were upregulated at 4 through $24 \mathrm{~h}$ after the application of $3.2 \mathrm{~mm} \mathrm{~Pb}$ compared with the control. At the $0.5 \mathrm{~mm}$ level, its expression was upregulated only at $24 \mathrm{~h}$ after treatment. The expression of $\mathrm{Chl} \mathrm{Cu} / \mathrm{Zn}$-SOD gene was upregulated in both 0.5 and $3.2 \mathrm{~mm} \mathrm{~Pb}$ treatments at 2, 4, and $6 \mathrm{~h}$ and was then below the levels of control at $24 \mathrm{~h}$ after the application of $\mathrm{Pb}$, and the
Table 3. Soluble protein and malondialdehyde (MDA) content in perennial ryegrass subjected to 0.5 and $3.2 \mathrm{~mm} \mathrm{~Pb}$ in a hydroponic system using half-strength Hoagland's solution for $7 \mathrm{~d}$.

\begin{tabular}{lcc}
\hline Pb treatment $(\mathrm{mM})$ & MDA $\left(\mathrm{nM} \cdot \mathrm{g}^{-1}\right)$ & Soluble protein $\left(\mathrm{mg} \cdot \mathrm{g}^{-1}\right)$ \\
\hline 0 & $7.4 \mathrm{~b}^{\mathrm{z}}$ & $5.0 \mathrm{a}$ \\
0.5 & $6.1 \mathrm{c}$ & $5.6 \mathrm{a}$ \\
3.2 & $13.4 \mathrm{a}$ & $3.5 \mathrm{~b}$
\end{tabular}

${ }^{\mathrm{z}}$ Means within a column followed by the same letters were not significantly different at the $P=0.05$ level based on Fisher's least significant difference test.

peak value of transcript existed at 4 and $2 \mathrm{~h}$ after the application for the 0.5 and $3.2 \mathrm{~mm} \mathrm{~Pb}$ treatments, respectively (Table 5). The transcript of Cyt $\mathrm{Cu} / \mathrm{Zn}-\mathrm{SOD}$ mRNA increased at 6 and $4 \mathrm{~h}$ after treatment with 3.2 and $0.5 \mathrm{~mm} \mathrm{~Pb}$, respectively (Table 5). The expression of FeSOD gene in perennial ryegrass showed upregulation at 4 and $24 \mathrm{~h}$ after the application of $3.2 \mathrm{~mm} \mathrm{~Pb}$, whereas at 4 and $6 \mathrm{~h}$ after the treatment of $0.5 \mathrm{~mm} \mathrm{~Pb}$ (Table 5).

Elevated expression of $A P X$ gene in perennial ryegrass was only detected $4 \mathrm{~h}$ after the application of $\mathrm{Pb}$ treatments, with the 
Table 4. Antioxidant enzyme activities of perennial ryegrass subjected to 0.5 and $3.2 \mathrm{~mm} \mathrm{~Pb}$ in a hydroponic system using half-strength Hoagland's solution for $7 \mathrm{~d}$.

\begin{tabular}{|c|c|c|c|}
\hline $\begin{array}{l}\text { Pb treatment } \\
(\mathrm{mM})\end{array}$ & Catalase & Peroxidase & $\begin{array}{l}\text { Superoxide } \\
\text { dismutase }\end{array}$ \\
\hline & \multicolumn{3}{|c|}{ 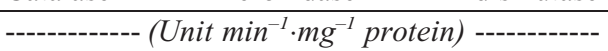 } \\
\hline 0 & $52.9 \mathrm{~b}^{\mathrm{z}}$ & $27.7 \mathrm{~b}$ & $1.9 \mathrm{a}$ \\
\hline 0.5 & $60.5 \mathrm{a}$ & $20.3 \mathrm{~b}$ & $1.1 \mathrm{~b}$ \\
\hline 3.2 & $30.7 \mathrm{c}$ & $40.8 \mathrm{a}$ & $0.5 \mathrm{c}$ \\
\hline
\end{tabular}

${ }^{\mathrm{z}}$ Means within a column followed by the same letters were not significantly different at the $P=0.05$ level based on Fisher's least significant difference test.

Table 5. Temporal transcription changes of different types of superoxide dismutase (SOD) gene in perennial ryegrass subjected to 0.5 and $3.2 \mathrm{mmol} \cdot \mathrm{L}^{-1} \mathrm{~Pb}$ in a hydroponic system using halfstrength Hoagland's solution at different times after the treatment. Values are presented as a ratio to the untreated control.

\begin{tabular}{|c|c|c|c|c|c|}
\hline \multirow{2}{*}{$\begin{array}{l}\mathrm{Pb} \text { treatment } \\
(\mathrm{mM})\end{array}$} & \multicolumn{5}{|c|}{ Sampling time after $\mathrm{Pb}$ treatment $(\mathrm{h})$} \\
\hline & 2 & 4 & 6 & 24 & 48 \\
\hline & \multicolumn{5}{|c|}{ 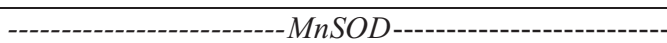 } \\
\hline 0.0 & $1.00 \mathrm{a}^{\mathrm{z}}$ & $1.00 \mathrm{~b}$ & $1.00 \mathrm{~b}$ & $1.00 \mathrm{c}$ & $1.00 \mathrm{a}$ \\
\hline 0.5 & $0.53 \mathrm{ab}$ & $0.55 \mathrm{c}$ & $0.82 \mathrm{~b}$ & $3.55 \mathrm{a}$ & $1.49 \mathrm{a}$ \\
\hline \multirow[t]{2}{*}{3.2} & $0.24 \mathrm{~b}$ & $2.77 \mathrm{a}$ & $5.73 \mathrm{a}$ & $1.24 \mathrm{~b}$ & $0.11 \mathrm{~b}$ \\
\hline & \multicolumn{5}{|c|}{------------------- $\mathrm{ChlCu} / \mathrm{ZnSOD}{ }^{\mathrm{y}}$} \\
\hline 0.0 & $1.00 \mathrm{c}$ & $1.00 \mathrm{c}$ & $1.00 \mathrm{c}$ & $1.00 \mathrm{a}$ & $1.00 \mathrm{a}$ \\
\hline 0.5 & $2.94 \mathrm{~b}$ & $8.37 \mathrm{a}$ & $5.82 \mathrm{a}$ & $0.17 \mathrm{~b}$ & $0.09 \mathrm{~b}$ \\
\hline 3.2 & $8.05 \mathrm{a}$ & $2.79 \mathrm{~b}$ & $3.98 \mathrm{~b}$ & $0.84 \mathrm{a}$ & $0.15 \mathrm{~b}$ \\
\hline & \multicolumn{5}{|c|}{------------------ $\mathrm{Cyt} C \mathrm{Cu} \mathrm{ZnSOD}$} \\
\hline 0.0 & $1.00 \mathrm{a}$ & $1.00 \mathrm{bc}$ & $1.00 \mathrm{~b}$ & $1.00 \mathrm{a}$ & $1.00 \mathrm{a}$ \\
\hline 0.5 & $0.25 \mathrm{~b}$ & $2.65 \mathrm{a}$ & $0.33 \mathrm{c}$ & $0.36 \mathrm{~b}$ & $0.11 \mathrm{~b}$ \\
\hline 3.2 & $1.60 \mathrm{a}$ & $1.21 \mathrm{~b}$ & $2.31 \mathrm{a}$ & $1.03 \mathrm{ab}$ & $0.44 \mathrm{~b}$ \\
\hline & & --"-- & FeSOD & & \\
\hline 0.0 & $1.00 \mathrm{a}$ & $1.00 \mathrm{c}$ & $1.00 \mathrm{~b}$ & $1.00 \mathrm{~b}$ & $1.00 \mathrm{a}$ \\
\hline 0.5 & $0.73 \mathrm{a}$ & $1.35 \mathrm{~b}$ & $1.83 \mathrm{a}$ & $0.60 \mathrm{c}$ & $0.29 \mathrm{~b}$ \\
\hline 3.2 & $0.85 \mathrm{a}$ & $3.18 \mathrm{a}$ & $0.52 \mathrm{c}$ & $1.58 \mathrm{a}$ & $0.41 \mathrm{~b}$ \\
\hline
\end{tabular}

${ }^{\mathrm{z}}$ Means within a column followed by the same letters were not significantly different at the $P=0.05$ level based on Fisher's least significant difference test.

${ }^{\text {y }} \mathrm{Chl} \mathrm{Cu} / \mathrm{ZnSOD}=$ chloroplastic $\mathrm{Cu} / \mathrm{ZnSOD}$ gene, $C y t \mathrm{Cu} / \mathrm{ZnSOD}=$ cytosolic $\mathrm{Cu} / \mathrm{ZnSOD}$ gene.

$3.2 \mathrm{~mm} \mathrm{~Pb}$ treatment had a higher expression than the $0.5 \mathrm{~mm} \mathrm{~Pb}$ treatment (Table 6). The expression of GPX gene showed a similar trend to $A P X$ gene except the increase was found at $2 \mathrm{~h}$ after the application of $0.5 \mathrm{~mm} \mathrm{~Pb}$. The expression of $G R$ showed sustained increase from 4 to $24 \mathrm{~h}$ after the application of $\mathrm{Pb}$ in both 3.2 and $0.5 \mathrm{~mm}$ treatments. The $P O D$ gene expression was upregulated by $0.5 \mathrm{~mm} \mathrm{~Pb}$ at 4 and $6 \mathrm{~h}$ after the treatment. However, increased POD mRNA levels were detected for the $3.2 \mathrm{~mm} \mathrm{~Pb}$ treatment at all but the $24 \mathrm{~h}$ sampling times after the application of $\mathrm{Pb}$ (Table 6).

\section{Discussion}

The growth of perennial ryegrass was inhibited when exposed to $0.5 \mathrm{~mm} \mathrm{~Pb}$, which was in agreement with the findings
Table 6. Temporal transcription changes of peroxisomal-type ascorbate peroxidase $(p A P X)$, glutathione peroxidase $(G P X)$, glutathione reductase $(G R)$, and peroxidase $(P O D)$ genes in perennial ryegrass subjected to 0.5 and $3.2 \mathrm{mmol} \cdot \mathrm{L}^{-1} \mathrm{~Pb}$ in a hydroponic system using half-strength Hoagland's solution at different times after the treatment. Values are presented as a ratio to the untreated control.

\begin{tabular}{|c|c|c|c|c|c|}
\hline \multirow{2}{*}{$\begin{array}{l}\mathrm{Pb} \text { treatment } \\
(\mathrm{mM})\end{array}$} & \multicolumn{5}{|c|}{ Sampling time after $\mathrm{Pb}$ treatment $(\mathrm{h})$} \\
\hline & 2 & 4 & 6 & 24 & 48 \\
\hline & & - & $p A P X--$ & --------- & -------- \\
\hline 0.0 & $1.00 \mathrm{a}^{\mathrm{z}}$ & $1.00 \mathrm{c}$ & $1.00 \mathrm{~b}$ & $1.00 \mathrm{a}$ & $1.00 \mathrm{a}$ \\
\hline 0.5 & $0.60 \mathrm{~b}$ & $1.91 \mathrm{~b}$ & $0.54 \mathrm{a}$ & $0.57 \mathrm{a}$ & $0.57 \mathrm{ab}$ \\
\hline 3.2 & $0.49 \mathrm{~b}$ & $5.52 \mathrm{a}$ & $1.08 \mathrm{ab}$ & $0.99 \mathrm{a}$ & $0.52 \mathrm{~b}$ \\
\hline 0.0 & $1.00 \mathrm{~b}$ & $1.00 \mathrm{~b}$ & $1.00 \mathrm{a}$ & $1.00 \mathrm{a}$ & $1.00 \mathrm{a}$ \\
\hline 0.5 & $2.48 \mathrm{a}$ & $2.60 \mathrm{a}$ & $1.93 \mathrm{a}$ & $0.85 \mathrm{a}$ & $0.89 \mathrm{~b}$ \\
\hline 3.2 & $1.11 \mathrm{~b}$ & $2.85 \mathrm{a}$ & $1.26 \mathrm{a}$ & $0.50 \mathrm{a}$ & $0.48 \mathrm{c}$ \\
\hline & & & $--G R$--- & & \\
\hline 0.0 & $1.00 \mathrm{a}$ & $1.00 \mathrm{~b}$ & $1.00 \mathrm{~b}$ & $1.00 \mathrm{c}$ & $1.00 \mathrm{a}$ \\
\hline 0.5 & $0.50 \mathrm{~b}$ & $2.64 \mathrm{a}$ & $1.78 \mathrm{a}$ & $6.69 \mathrm{a}$ & $1.32 \mathrm{a}$ \\
\hline 3.2 & $1.00 \mathrm{ab}$ & $1.91 \mathrm{ab}$ & $2.19 \mathrm{a}$ & $2.99 \mathrm{~b}$ & $0.79 \mathrm{a}$ \\
\hline & --------- & & $P O D$ & & ---------- \\
\hline 0.0 & $1.00 \mathrm{bc}$ & $1.00 \mathrm{~b}$ & $1.00 \mathrm{~b}$ & $1.00 \mathrm{a}$ & $1.00 \mathrm{~b}$ \\
\hline 0.5 & $1.23 \mathrm{~b}$ & $6.25 \mathrm{a}$ & $4.46 \mathrm{a}$ & $1.01 \mathrm{a}$ & $0.88 \mathrm{~b}$ \\
\hline 3.2 & $4.48 \mathrm{a}$ & $4.15 \mathrm{a}$ & $2.35 \mathrm{a}$ & $0.45 \mathrm{~b}$ & $3.96 \mathrm{a}$ \\
\hline
\end{tabular}

${ }^{2}$ Means followed by the same letters within a column for each gene are not significantly different based on Fisher's least significant difference test at $P<0.05$.

by Carlson and Rolfe (1979). The concentration of Chl $a$ and total $\mathrm{Chl}$ was not affected by $\mathrm{Pb}$ treatment, whereas the content of $\mathrm{Chl} b$ was increased by high level of $\mathrm{Pb}$. Since higher concentration of $\mathrm{Chl} b$ existed in stunted perennial ryegrass, it might be caused by faster decrease of cell number and cell size or by impaired ability of water uptaking resulted by metal toxicity. Therefore, plant biomass may be a better indicator of perennial ryegrass tolerance to $\mathrm{Pb}$ than $\mathrm{Chl}$ content.

Lipid peroxidation is a sensitive marker of oxidative stress (Polle et al., 1997), which can be reflected by its final decomposition product, MDA. Results from this study showed a substantial increase of MDA content in leaf tissues when perennial ryegrass was exposed to $3.2 \mathrm{~mm} \mathrm{~Pb}$. However, the MDA content was lower than the control at the $0.5 \mathrm{~mm} \mathrm{~Pb}$ treatment, indicating that an effective defense mechanism was in action. Circumstantial evidence also came from the content of soluble protein in $0.5 \mathrm{~mm} \mathrm{~Pb}$ treatment, which was not different from that of the control. Furthermore, the activity of CAT increased at $0.5 \mathrm{~mm} \mathrm{~Pb}$ compared with the control, indicating that CAT played an important role in scavenging $\mathrm{ROS}$, as was reported in other organisms under low dose of $\mathrm{Pb}$ (Cho and Seo, 2005). The present study showed that POD activity in $0.5 \mathrm{~mm} \mathrm{~Pb}$ treatment remained at the same level as that in the control. This may be explained by the fact that POD catalyzes conversion of $\mathrm{H}_{2} \mathrm{O}_{2}$ to generate phenoxy compounds in the downstream of ROS scavenging (Greppin et al., 1986). This result was also supported by other research findings where $\mathrm{POD}$ activity increased in response to $\mathrm{Pb}$ in $A$. thaliana, rice (Oryza sativa), maize, horse gram, and bengal gram 
(Lummerzheim et al., 1995; Reddy et al., 2005; Verma and Dubey, 2003; Zacchini et al., 2003).

Superoxide dismutase is one of the most important members of the enzymatic antioxidant defense system against ROS (Alscher et al., 2002). At the end of $7 \mathrm{~d}$ exposure to Pb, SOD activity was less in the $3.2 \mathrm{~mm}$ treatment than in the $0.5 \mathrm{~mm}$ treatment. Dose-dependent SOD inhibition by $\mathrm{Pb}$ also was reported by Zhang et al. (2007).

Three types of SODs, FeSOD, MnSOD, cyt Cu/ZnSOD, and chl Cu/ZnSOD, are currently recognized (Tsang et al., 1991). In this study, Q-PCR demonstrated variations of these genes in terms of expression levels and time course. Similarly, Liu et al. (2009) reported that the SOD gene expression was substantially increased within $3 \mathrm{~h}$ of $\mathrm{Pb}$ treatment and then gradually declined to a stable level. Four genes encoding for SOD enzymes were all upregulated in response to $\mathrm{Pb}$ treatment in $A$. thaliana seedlings (Liu et al., 2009). Evidence of involvement of SOD enzymes in $\mathrm{Pb}$ tolerance also came from transgenic $A$. thaliana line (Kovalchuk et al., 2005), which showed overexpression of $M n S O D$ and increased tolerance to $\mathrm{Pb}$, salinity, drought, and freezing (McKersie et al., 1993; Tanaka et al., 1999; Wang et al., 2004).

Both APX and GR are indispensable components of ascorbateglutathione (GSH) pathway generated mainly in chloroplasts and other cell organelles. As one of the key enzymes of antioxidative defense system, APX uses the reducing power of ascorbic acid to scavenge harmful $\mathrm{H}_{2} \mathrm{O}_{2}$ and regulates the cellular concentration of $\mathrm{O}_{2}{ }^{-}$and $\mathrm{H}_{2} \mathrm{O}_{2}$ (Asada, 1992). Glutathione reductase is involved in the formation of reduced GSH molecules, which regulate redox in cells and play a critical role in protecting plants against oxidative stress (Grant et al., 1996; Sanchez-Fernandez et al., 1997). In this study, the Pb-induced expression of $G R$ and $A P X$ suggested that ROS detoxification was at least partly implemented through the ascorbate-GSH cycle in perennial ryegrass. Brunet et al. (2009) reported that there was an overaccumulation of transcripts coding for GR in grass pea, along with slight increase of mRNA of various APX in response to $\mathrm{Pb}$ stress. Accumulation of mRNA and increased activity of APX was also found in other plant species (Mishra et al., 2006; Verma and Dubey, 2003).

Results from this study suggested that GPX probably served as an intrinsic defense against $\mathrm{Pb}$-induced oxidative damage in perennial ryegrass. It was consistent with the elevated GPX activity in rice exposed to $\mathrm{Pb}$ (Verma and Dubey, 2003). Also, both the 0.5 and $3.2 \mathrm{~mm}$ levels of $\mathrm{Pb}$ induced significant increase of $P O D$ mRNA accumulation in perennial ryegrass. This result was in agreement with other study where 20 genes encoding POD enzymes were upregulated in the seedlings of A. thaliana in response to $\mathrm{Pb}$ treatment (Liu et al., 2009).

In present study, the genes encoding antioxidant enzymes were upregulated within a few hours after the exposure to $\mathrm{Pb}$. However, their expression levels were the same as or below that in untreated controls after 24 or $48 \mathrm{~h}$. Note also, the SOD activity was below the level of control in plants after $7 \mathrm{~d}$ of $\mathrm{Pb}$ treatment. Therefore, antioxidant enzymes might be responsible for the early stage defense to $\mathrm{Pb}$-induced oxidative stress in ryegrass. Only $P O D$ gene retained at upregulated levels at $48 \mathrm{~h}$ after treatment with $3.2 \mathrm{~mm} \mathrm{~Pb}$, coincidental with the elevated enzyme activity of POD $7 \mathrm{~d}$ after the subjection to $\mathrm{Pb}$ at $3.2 \mathrm{~mm}$. The results indicated that the time course of plant defense system in response to $\mathrm{Pb}$ was better defined at gene levels than at the enzyme levels, although the results of gene expression conformed to the enzyme activity.
In conclusion, the effects of $\mathrm{Pb}$ on perennial ryegrass were reflected at the growth, physiological, enzyme, and gene levels. Although antioxidant enzymes may be used as indicators of the responses in perennial ryegrass to $\mathrm{Pb}$ at an early stage of exposure, gene expression profiles provided more accurate time course of the activation of those systems.

\section{Literature Cited}

Alscher, R.G., N. Erturk, and L.S. Heath. 2002. Role of superoxide dismutase (SODs) in controlling oxidative stress in plants. J. Expt. Bot. 53:1331-1341.

Arienzo, M., P. Adamo, and V. Cozzolino. 2004. The potential of Lolium perenne for revegetation of contaminated soil from a metallurgical site. Sci. Total Environ. 319:13-25.

Asada, K. 1992. Ascorbate peroxidase: A hydrogen peroxide scavenging enzyme in plants. Plant Physiol. 85:235-241.

Bian, S.M. and Y.W. Jiang. 2009. Reactive oxygen species, antioxidant enzyme activities and gene expression patterns in leaves and roots of kentucky bluegrass in response to drought stress and recovery. Sci. Hort. 120:264-270.

Bidar, G., G. Garçon, C. Pruvot, D. Dewaele, F. Cazier, F. Douay, and P. Shirali. 2007. Behavior of Trifolium repens and Lolium perenne growing in a heavy metal contaminated field: Plant metal concentration and phytotoxicity. Environ. Pollut. 147:546-553.

Bradford, M. 1976. A rapid and sensitive method for the quantitation of microgram quantities of protein utilizing the principle of proteindye binding. Anal. Biochem. 72:248-254.

Brunet, J., G. Varrault, Y. Zuily-Fodil, and A. Repellin. 2009. Accumulation of lead in the roots of grass pea (Lathyrus sativus L.) plants triggers systemic variation in gene expression in the shoots. Chemosphere 77:1113-1120.

Byrne, S.L., K. Durandeau, I. Nagy, and S. Barth. 2010. Identification of $\mathrm{ABC}$ transporters from Lolium perenne L. that are regulated by toxic levels of selenium. Planta 231:901-911.

Carlson, R.W. and G.L. Rolfe. 1979. Growth of rye grass and fescue as affected by lead-cadmium-fertiliser interaction. J. Environ. Qual. $8: 348-352$.

Chance, B. and S.K. Maehly. 1955. Assay of catalase and peroxidases. Methods Enzymol. 2:764-775.

Cho, U.H. and N.H. Seo. 2005. Oxidative stress in Arabidopsis thaliana exposed to cadmium is due to hydrogen peroxide accumulation. Plant Sci. 168:113-120.

Chowdhury, R.S. and M.A. Choudhuri. 1985. Hydrogen peroxide metabolism as an index of water stress tolerance in jute. Physiol. Plant. 65:476-480.

Foito, A., S.L. Byrne, T. Shepherd, D. Stewart, and S. Barth. 2009. Transcriptional and metabolic profiles of Lolium perenne L. genotypes in response to a PEG-induced water stress. Plant Biotechnol. J. 7:719-732.

Foyer, C.H., P. Descourvieres, and K.J. Kunert. 1994. Protection against oxygen radicals: An important defense mechanism studied in transgenic plants. Plant Cell Environ. 17:507-523.

Godbold, D.L. and C. Kettner. 1991. Lead influences root growth and mineral nutrition of Picea abies seedlings. J. Plant Physiol. 139:95-99.

Grant, C.M., F.H. MacIvr, and I.W. Dawes. 1996. Glutathione is an essential metabolite required for resistance to oxidative stress in the yeast Saccharomyces cerevisiae. Curr. Genet. 29:511-515.

Greppin, H., C. Panel, and T. Gaspar. 1986. Molecular and physiological aspects of plant peroxidases. University of Geneva, Geneva, Switzerland.

Heath, R.N. and H. Packer. 1968. Photoperoxidation in isolated chloroplasts. Kinetics and stoichiometry of fatty acid peroxidation. Arch. Biochem. Biophys. 125:189-198.

Hiscox, T.D. and G.F. Israelstam. 1979. A method for the extraction of chlorophyll from leaf tissues without maceration. Can. J. Bot. 57:1332-1334. 
Hoagland, D.R. and D.I. Arnon. 1950. The water culture method for growing plants without soil. California Agr. Expt. Sta. Circ. 347.

Islam, E., D. Liu, T. Li, X. Yang, X. Jin, Q. Mahmood, S. Tian, and J. Li. 2008. Effect of $\mathrm{Pb}$ toxicity on leaf growth, physiology and ultrastructure in the two ecotypes of Elsholtzia argyi. J. Hazard. Mater. 154:914-926.

Kastori, R., M. Petrovic, and N. Petrovic. 1992. Effect of excess lead, cadmium, copper and zinc on water relations in sunflower. J. Plant Nutr. 15:2427-2439.

Kim, D.W., J., Shibato, G.K. Agrawal, S. Fujihara, H. Iwahashi, H. Kim du, IeS Shim, and R. Rakwal. 2007. Gene transcription in the leaves of rice undergoing salt-induced morphological changes (Oryza sativa L.). Mol. Cells 24:45-59.

Kovalchuk, I., V. Titov, B. Hohn, and O. Kovalchuk. 2005. Transcriptome profiling reveals similarities and differences in plant responses to cadmium and lead. Mutat. Res. 570:149-161.

Lee, J.M., J.R. Roche, D.J. Donaghy, A. Thrush, and P. Sathish. 2010. Validation of reference genes for quantitative RT-PCR studies of gene expression in perennial ryegrass (Lolium perenne L.). BMC Mol. Biol. 11:8.

Liu, D., T.Q. Li, X.F. Jin, X.E. Yang, E. Islam, and Q. Mahmood. 2008. Lead induced changes in the growth and antioxidant metabolism of the lead accumulating and non-accumulating ecotypes of Sedum alfredii. J. Integr. Plant Biol. 50:129-140.

Liu, T., S.Y. Liu, H. Guan, L.G. Ma, Z.L. Chen, H.Y. Gu, and L.J. Qu. 2009. Transcriptional profiling of Arabidopsis seedlings in response to heavy metal lead $(\mathrm{Pb})$. Environ. Exp. Bot. 67:377-386.

Lummerzheim, M., M. Sandroni, C. Castresana, D. De Oliveira, M. Van Montagu, D. Roby, and B. Timmerman. 1995. Comparative microscopic and enzymatic characterization of the leaf necrosis induced in Arabidopsis thaliana by lead nitrate and by Xanthomanas campestris pv. Campestris after foliar spray. Plant Cell Environ. 18:499-509.

Magrini, K.D., A. Basu, J.R. Spotila, H.W. Avery, L.W. Bergman, R. Hammond, and S. Anandan. 2008. DNA microarrays detect effects of soil contamination on Arabidopsis thaliana gene expression. Environ. Toxicol. Chem. 27:2476-2487.

Malecka, A., W. Jarmuszkiewicz, and B. Tomaszewska. 2001. Antioxidative defense to lead stress in subcellular compartments of pea root cells. Acta Biochim. Pol. 48:687-698.

McKersie, B.D., Y. Chan, M. de Beus, S.R. Bowley, C. Bowler, D. Inzé, K. D'Halluin, and J. Botterman. 1993. Superoxide dismutase enhances tolerance of freezing stress in transgenic alfalfa (Medicago sativa L.). Plant Physiol. 103:1155-1163.

Mishra, S., S. Srivastava, R.D. Tripathi, R. Kumar, C.S. Seth, and D.K. Gupta. 2006. Lead detoxification by coontail (Ceratophyllum demersum L.) involves induction of phytochelatins and antioxidant system in response to its accumulation. Chemosphere 65:1027-1039.

Mittler, R. 2002. Oxidative stress, antioxidants and stress tolerance. Trends Plant Sci. 7:405-410.

Pichtel, J. and C.A. Salt. 1998. Vegetative growth and trace metal accumulation on metalliferous wastes. J. Environ. Qual. 27:618-624.

Polle, A., M. Eiblemeier, L. Sheppard, and M. Murray. 1997. Responses of antioxidative enzymes to evaluated $\mathrm{CO}_{2}$ in leaves of beech (Fagus sylvatica L.) seedlings grown under a range of nutrient regimes. Plant Cell Environ. 20:1317-1321.

Rashid, A. and R. Popovic. 1990. Protective role of $\mathrm{CaCl}_{2}$ against $\mathrm{Pb}^{2+}$ inhibition in photosystem II. FEBS Lett. 271:181-184.

Reddy, A., S. Kumar, G. Jyothsnakumari, S. Thimmanaik, and C. Sudhakar. 2005. Lead induced changes in antioxidant metabolism of horsegram (Macrotyloma uniflorum (Lam.) Verdc.) and bengalgram (Cicer arietinum L.). Chemosphere 60:97-104.

Sanchez-Fernandez, R., M. Fricker, L.B. Corben, N.S. White, N. Sheard, C.J. Leaver, M. Van Montagu, D. Inze, and M.J. May. 1997. Cell proliferation and hair tip growth in the Arabidopsis root are under mechanistically different forms of redox control. Proc. Natl. Acad. Sci. USA 94:2745-2750.

Schutzendubel, A. and A. Polle. 2002. Plant responses to abiotic stresses: Heavy metal-induced oxidative stress and protection by mycorrhization. J. Expt. Bot. 53:1351-1365.

Smith, R.A.H. and A.D. Bradshaw. 1979. The use of metal tolerant plant populations for the reclamation of metalliferous wastes. J. Appl. Ecol. 16:595-612.

Srivastava, A.K., P. Venkatachalam, K.G. Raghothama, and S.V. Sahi. 2007. Identification of lead-regulated genes by suppression subtractive hybridization in the heavy metal accumulator Sesbania drummondii. Planta 225:1353-1365.

Sun, S.Q., M. He, T. Cao, Y.C. Zhang, and W. Han. 2009. Response mechanisms of antioxidants in bryophyte (Hypnum plumaeforme) under the stress of single or combined $\mathrm{Pb}$ and/or Ni. Environ. Monit. Assess. 149:291-302.

Tanaka, K., T. Hibino, Y. Hayashi, A. Tanaka, S. Kishitani, T. Takabe, and S. Yokota. 1999. Salt tolerance of transgenic rice overexpression yeast mitochondrial Mn-SOD in chloroplasts. Plant Sci. 148:131-138.

Tsang, E.W.T., C. Bowler, D. Herouart, W. Van Camp, R. Villarroel, C. Genetello, M. Van Montagu, and D. Inze. 1991. Differential regulation of superoxide dismutases in plants exposed to environmental stress. Plant Cell 3:783-792.

Verma, S. and R.S. Dubey. 2003. Lead toxicity induces lipid peroxidation and alters the activities of antioxidant enzymes in growing rice plants. Plant Sci. 164:645-655.

Wang, Y.H., Y. Ying, J. Chen, and X.C. Wang. 2004. Transgenic Arabidopsis overexpressing Mn-SOD enhanced salt-tolerance. Plant Sci. 167:671-677.

Wilkins, P.W. and M.O. Humphreys. 2003. Progress in breeding perennial forage grasses for temperate agriculture. J. Agr. Sci. 140:129-150.

Zacchini, M., E. Rea, M. Tullio, and M. de Agazio. 2003. Increased antioxidative capacity in maize calli during and after oxidative stress induced by a long lead treatment. Plant Physiol. Biochem. 41:49-54.

Zhang, F.Q., Y.S. Wang, Z.P. Lou, and J.D. Dong. 2007. Effect of heavy metal stress on antioxidative enzymes and lipid peroxidation in leaves and roots of two mangrove plant seedlings (Kandelia candel and Bruguiera gymnorrhiza). Chemosphere 67:44-50.

Zhang, J.X. and M.B. Kirkham. 1994. Drought-stress-induced changes in activities of superoxide dismutase, catalase, and peroxidase in wheat species. Plant Cell Physiol. 35:785-791. 